\title{
SMART HERITAGE BUILDINGS AS A TOOL TO ACHIEVE TOURISM COMPETITIVENESS
}

Maysa Ali Elsayed SLIEM, Yasmine Sabry HEGAZI, Mahmoud Mohamed Fathy EL-ALFY*

Architecture department, Faculty of Engineering, Zagazig University, Egypt

\begin{abstract}
The competitiveness indicators of the tourism sector have been of great importance to international institutions for the role played by this sector in the economy. The appearance of architectural intelligence and information technology and communications has also led to increased competition in tourism projects. Here is the problem of research, heritage buildings suffered a lot of low competitiveness, since it does not rely on the smart system, and overlapping the competencies of the various ministries and lack of coordination among them, which adversely affected the competitiveness of tourism associated with buildings Heritage. As a result, the research aims to develop mechanisms to gain a competitive advantage by introducing intelligence as a tool that increases the competitiveness of heritage buildings The research is based on a common strategy between the descriptive approach and the analytical approach to the case study and the evaluation of the experience of introducing the characteristics of architectural intelligence as a competitive advantage to improve the efficiency of the heritage buildings, which is reflected in the visitors experience and the rate of visit to the heritage building.

Keywords

Heritage Buildings, Competitiveness, Architectural Intelligence Features, Efficiency Improvement, Intelligent Building index (IBI).
\end{abstract}

\section{Introduction}

To develop mechanisms to increase the competitiveness of heritage buildings when rehabilitated by providing architectural features to enhance the efficiency of heritage buildings to achieve tourist competitiveness through high visits to the building and to provide good visitors experience.

Tourism is considered one of the elements of economic development. Therefore, the World Tourism Organization, one of the United Nations organizations that is concerned with the tourism affairs of countries, has alerted most developing countries to the need to manage tourism, especially what affects heritage areas. In the year 12 the International Council of Archaeological Sites and Museums (ICOMOS) discussed The tourism charter that calls on all concerned organizations to support the tourism industry and participate in preparing a guide that will be implemented by countries to promote that industry (ICOMOS). Egypt contains many heritage buildings of value that cannot be overlooked and which is considered a national revolution and an important economic resource for Egypt in the field of cultural tourism. Heritage buildings have suffered from a decrease in their competitiveness due to the overlapping competencies of the Ministry of Endowments as the owner of some antiquities or

\footnotetext{
*Corresponding author: info-eng@zu.edu.eg
} 
the Ministry of Culture or the Ministry of Housing and the lack of coordination between them, which has a negative impact on the competitiveness of tourism related to heritage buildings and on its economic return as a result of the conflict in decision-making. Rehabilitated heritage buildings as a tool to achieve a competitive advantage and raise the efficiency of heritage buildings, which will be reflected in the visitors' experience The rate of visit to the heritage building

\section{Research problem:}

The lack of achievement of heritage buildings for tourism competitiveness as a result of the low efficiency, which affects the provision of good visitors experience and the rate of visit to the building, and the impact on the economic and development benefits of the surrounding areas.

\section{Research Methodology:}

The research methodology consists of combined strategy as following: 1st :use Descriptive method To identify the concept of competitiveness of the tourism sector and Through identifying the concept of competitiveness of the tourism sector and the mechanisms of achieving the advantage of passive and identify each generation of generations of architectural intelligence features. Learn about the way to assess the intelligence of heritage buildings after the introduction of intelligence as a competitive advantage using the features of intelligence and the method of smart building index

2nd : use analytical method through the extraction of the features of the methodology to impart the features of architectural intelligence, through the analysis of a global heritage building that collected more than one generation and the impact on the annual visit rate of the building.

The concept of competitiveness of the tourism sector is the Organization for Economic Cooperation and Development

Organization for Economic Co-operation and (OECD) (Development)

The first to lay the foundations for the idea of competitiveness in tourism, indicators were published to measure the competitiveness of tourist areas in 2013, and the competitiveness of the tourism sector is defined as the ability of the tourism sector institutions in a country to achieve continuous success in international markets without relying on governmental support and protection. To the distinction of these countries in this competitive sector whose institutions and establishments are able to confront competition, whether domestic, internal or external, by preserving their share of the market and working to develop them continuously and achieve profits based on high rates of productivity and capable of innovation and continuous development. Competitive advantage in heritage buildings related to two main 
dimensions, which are the perceived value of the tourism product for tourists, and confirmation of the state of excellence of the tourism product; The concept of competitiveness varies, as indicated by Michael Porter, according to the level of analysis, either at the level of the establishment, industry or country, and it will be reviewed from a tourism perspective as follows:

1- Competitiveness according to the establishment (hypothetical building) is the ability of the buildings of the buildings to maintain in the market or increase their share in the global market on a continuous basis (1995, UNCTAD), and the buildings of the buildings are considered competitive if they are able to maintain the continuity of their proceeds over time, or Increase its share of the global market.

2- Competitiveness according to the industry (the cultural tourism industry: the cultural tourism industry must have a high competitive advantage, achieve high rates of productivity, and be subject to innovation and renewal, which contributes to the high ability to maintain this level.

3- Competitiveness according to the state is the degree to which a country reaches in producing a tourism product that provides high-quality services that suit global tastes, and adapts to changing demand conditions. DEPRA) (june 1998) represents increased productivity, technological innovation, and political stability.

Creating a competitive advantage in the heritage building:

Creating a competitive advantage for the hypothetical building according to the Porter method is due to its renewal and innovation, and thus affects tourism as an industry and then the state derives its competitiveness from the erosion of the industry as the relationship between them is an integrative relationship, where one of them leads to the other. Porter has defined general strategies for competitiveness to reach an advantage. Competitiveness that makes the hypothetical building able to compete in tourism, and is summarized as follows:

\section{1- Cost: Cost Leadership Strategy}

By producing a low-cost tourism product among its competitors while preserving quality, in addition to developing the product in a manner that does not conflict with reducing the cost, and this needs monitoring and reporting on a continuous and scheduled basis.

\section{2- Differentiation Strategy:}

Reaching a technical increase in the provision of services and working to meet the expectations and desires of tourists and ensure their satisfaction, which confirms its presence in the global market.

\section{3- Focus Strategy:}


This strategy aims to build a competitive advantage targeting a specific segment of the market and to reach better sites in the tourism market, by satisfying the needs and desires of the cultural tourist.

Adding architectural intelligence features to existing heritage buildings as a competitive advantage:

The competitive advantage of the buildings is achieved by enhancing them with the features of architectural intelligence in order to create a productive and effective environment to achieve the goal of operating the building in a more efficient manner that increases its ability to provide a good visitor experience and this is achieved through general strategies for competitiveness of reducing the cost and excellence by increasing the technology in providing Services that enhance the supply to meet the changing needs of tourists to increase demand for it, and focus on targeting tourists who have cultural desires. Architectural intelligence traits can be determined to fall into four main generations, so the generation does not end with the emergence of the next generation.

1- Automation (1st generation) Automation:

Automation or self-control in the functions of the mini is the basic principle and the main feature on which the idea of the intelligence of the mini is based, it is an indispensable feature of any multitasking called a smart mini, where the smart building conforms to the surroundings by monitoring changes and developments through sensors that the decision has been made. According to a previously prepared database, the self-disposition was done, and the automation feature of the mini is inferred through the smart systems available in the building, which are controlled automatically without the slightest human intervention, which results in operating efficiency through automated systems that enable the building to respond immediately to internal or external variables to the mini to ensure the quality Mini, or alert when exposed to the risk of prioritizing intervention to reduce maintenance costs.

2- Responsive (second generation):

This generation is characterized by the integration of systems where all the building equipment works with electrical energy that is linked to an information network to be controlled through an information program, so it becomes possible to interact between the electricity network and the information structure inside the building to manage the electricity network, as well as manage all systems and equipment that operate with electricity from a distance The external and internal changes, as well as the user's requirements, are monitored by a group of cells, each of which monitors a specific type of these changes, and the variables are extrapolated and the user's desires are identified as they send this data through local area networks to the database 
to make a decision according to To pre-feed it, and the decision sent to the vocabulary of the mini and its equipment is executed by responding through the local networks

3- Compatibility with the environment and sustainability (third generation:

The concern for environmental issues and the provision of current needs without disrupting future needs is no longer a feature of peoples' well-being, but rather an essential element and considering them as a pillar of architectural intelligence, which should be integrated with the features of automation and response to arrive at an architectural product. The success of the mini is represented in achieving the needs of its users related to the climate, in addition to the harmony of the building with the surrounding site by monitoring variables and developments through sensors that provide information about the results of the system's work and some environmental conditions that affect its performance. Sift this information directly into the automated system. This enables the system to take the necessary mining. This system is what distinguishes automation from mechanization as it works to perform tasks with automatic control equipment capable of self-regulation and decision-making according to a pre-prepared database that has been self-acting.

Equipping heritage buildings with the necessary technologies in order for building systems to be able to self-act through sensors monitoring cells and cabling solutions that are required to transmit information in its digital form.

- Programs for controlling air conditioning, for programs to rely on available energy sources.

- Natural lighting integration system with industrial lighting.

- Programs to reduce energy consumption rates of mini and automatic control of the building occupants' requirements.

4- virtual (fourth generation) virtuality:

The use of interactive technology such as augmented reality or virtual reality in heritage buildings and the presence of interactive display systems that create a simulation of ancient cultures by integrating them into the real environment, relying on information and communication technology and artificial intelligence technologies that help enhance the visitor experience and increase the material return, and to achieve virtualization For high-speed buildings, the following digital infrastructure is required that is capable of fast transporting services such as optical fibers

Hard ware, software that is able to convert traditional services into a digital form that can be handled over networks and sent to virtual environments

Wireless Application protocol telephones (WAP), and the development of conventional and interactive wireless mobile phones 
Building wireless information networks capable of linking smart building equipment with personal assistants or mobile phones, and using the international information network alongside them

Discussing the results:

1- The rate of visitation of the Renwick exhibition increased as a result of imparting architectural intelligence features when the building was rehabilitated, as it received more than 50, 000 visitors and 120 million in the first six months, and the Renwick Gallery exceeded its annual rate of visits before the renovation from 2000 to 2000 to 2000 visitors for the year 2015 , the costly use of interactive display systems and ensuring that the building responds to the demands of visitors through advanced communications, connecting the mini to the international network, improving the efficiency of the internal environment and having security and safety systems achieve the best of good visitors.

2- The degree of building intelligence is an indicator of the percentage of the building's efficiency achieved, as Moez Rati obtained an evaluation rate of $75 \%$ using the attributes of intelligence and achieving the four generations. He also obtained a forgetting to evaluate 74 9\% using the smart building guide. The competitiveness increased after adding the characteristics of intelligence in it after he achieved Strategies to reduce cost and excellence in providing service to visitors and focus on doubling the rate of visit as the digital demand for it increased after it was awarded the best art gallery and the "10 best attractions for the world" by USA Today newspaper. And he won many awards, including the MD Award for Excellence and Historical Restoration and 2013 Merit Award based on performance.

3- Energy consumption has been reduced, forgotten, and within the Retwelk exhibition, the introduction of intelligence causes the intelligence system that works to enhance the operating efficiency of the mini through automated systems that enable the mini to respond directly to internal or external variables and to enhance cost effectiveness as the actual cost of the whole life cycle of the smart heritage mini Much less than the cost for the life cycle of a normal hypothetical building due to its extreme energy savings, ease of maintenance, control over its systems and their development easily with the development of technology, which extends its life span and

Conclusion:

Al-Bahat proposed mechanisms to raise the efficiency of buildings in the buildings to achieve tourism competitiveness by imparting the characteristics of intelligence as a competitive advantage according to Porter's approach to achieve competitiveness strategies from reducing costs to achieving distinction and focus. The characteristics of architectural intelligence and 
evaluation also use (IBI) to ascertain the level of intelligence achieved as an indicator to raise the efficiency of the mini, and the research in its results showed that the higher the intelligence of the mini, the higher the rate of visit as a result of achieving good visitor experience and the ability to fulfill their changing desires, which is the most important factor in the tourism competitiveness of the building. Conceptualization, adding intelligence features achieves efficiency in operation, improves the level of comfort for users and visitors, enhances cost and reduces energy consumption, and the research recommends the need to form an integrated research team covering all disciplines related to smart heritage architecture to conduct specialized research and studies, to examine the possibility and ways to apply these strategies to the local reality. To prepare technical cadres to implement, operate and maintain the intelligence system inside buildings To raise its efficiency and achieve tourism competitiveness, and rehabilitation is not limited to restoration and maintenance only.

\section{References:}

1- www.un.org.

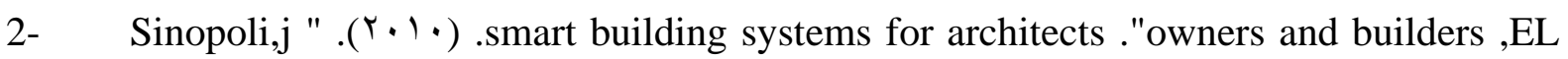
sevierinc., united states .p47.

3- $\quad$ artdaily.com.(n.d.).Retrievedfromhttp://artdaily.com/news/90763/SmithsonianAmerican-Art Museum-releases--Renwick-Gallery-WONDER-360--virtual-realityapp\#.W4r_us7XLIU.

4- Leonard, C \& et al. (2005). Intelligent Building Index. Hong kong: Asian Institute of intelligent buildings.

5- $\quad$ Atkin, Brian. ((1988)). Progress Towards Intelligent Buildings. New York: John Wiley $\&$ Sons.

6- Barrney, J.B. Brain. (1991). Resources and Sustaining Competitive Advantage. Journal Management, $p: 102$.

7- $\quad$ Boyle, Katherine. (18 July 2013.). "Renwick modeled it after the Louvre's Tuileries addition". Washington Post.

8- Caffrey,R. (2000). "building performance and occupant productivity". peronal Environment-Anew building focus. fourth world congress.

9- Comer, D. (2012). tourism and archeological heritage management. Springer, page 3.

10- Daniel 1. Prajogo and McDermott. (2011). Examining competitive priorities and competitive advantage in service organisations using Importance-Performance Analysis matrix. Vol. 21 Iss: 5, pp.465- 483. 
11- Development Economic policy Refrain analysis project (DEPRA) (june1998). "Enhancing Egypt's Export" final report. subimitted by Nathan Associate, p. p9.

12- $\quad$ Echols, Tucker. (June 24, 2014.). "David Rubenstein Gives \$5.4M for Renwick Gallery Renovation". Washington Business Journal.

13- international cultural tourism charte ICOMOS (1999).ICOMOS, international cultural tourism charter, managing tourism at places of heritage significance .managing tourism at places of heritage significance.

14- Porter, M. (1980). The competitive advantage of corporate philanthropy. Harvard business review.

15- Porter, M. (1990). The Competitive Advantage of Nations. Macmillan press, LTD, New York, P55.

16- Quaddus, J. Xu and M. (2013). Information Systems for Competitive Advantages.

17- Sinopoil, J. (2010). smart building systems for Architects, owners and Building. Elsevier press-An Imprint of Elsevier, oxford, $u k, p l$.

18- UNCTAD. (1995). Environment International Copetitivness and Development: Lessons From Empirial Studies. p. P.4.

19- Wigginton, Michael \& Harris, Jude. (2002). "intelligent skins". Architectural press, An Imprint of Elsevier, Linacre House, Jordan Hill, Oxford, UK, $p 39$.

20- wikipedia.org. (n.d.). Retrieved from https://en.wikipedia.org/wiki/Renwick_Gallery.

21- wjla.com is al jy https://wjla.com/news/local/renwick-gallery-virtual-reality .

22- www.architectmagazine.com

https://www.architectmagazine.com/technology/experiencingburning-man-in-virtualreality .

23- www.nps.gov. (n.d.). Retrieved from https://www.nps.gov/nr/travel/wash/dc27.htm .

24- www.wbdg.org. (n.d.). Retrieved from https://www.wbdg.org/additionalresources/casestudies/renwick-gallery .

25- Yardley, William) 2013" (Renwick Gallery of the Smithsonian American Art Museum." Washington Post.

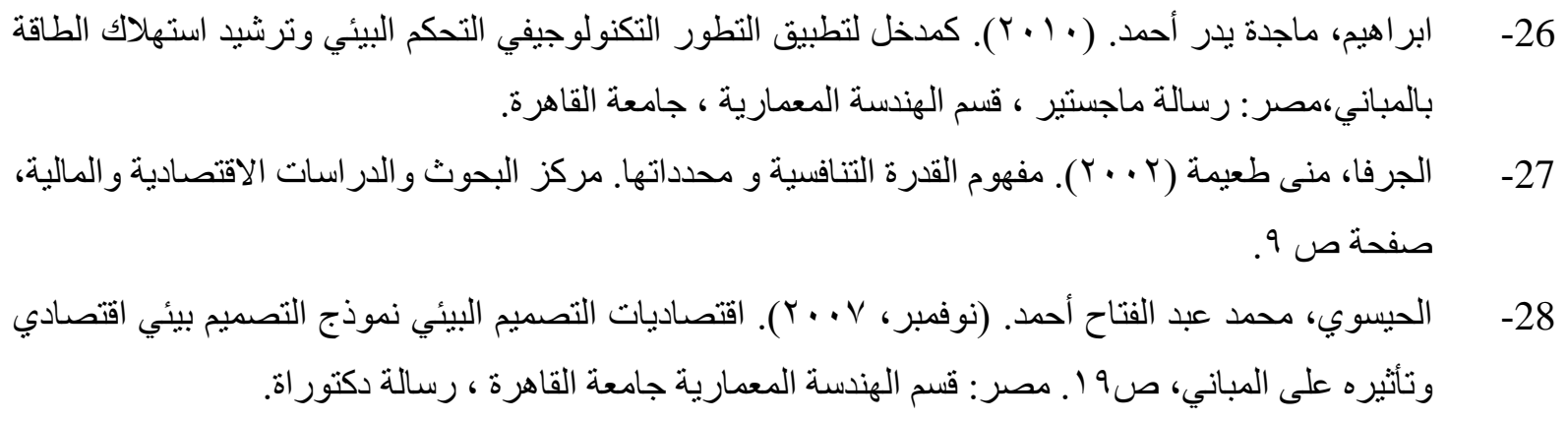




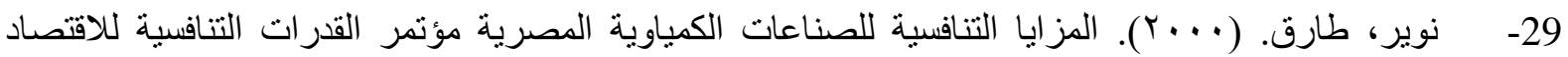
المصري. اقاق المستقبل نوفمبر . . . ب (صفحة ص999). مركز الدراسات وبحوت الدول النامية كلية الاقتصاد و العلوم السياسية جامعة القاهرة. عبد الكريم ، نبيل غالب ـ (^ . . ץ). الاتجاهات الحديثة للتصميم البيئي ـ نموذج للتصميم البيئي وترشيد الطاقة في المبني،مصر : رسالة ماجستير، قسم الهندسة المعمارية، جامعة القاهرة.

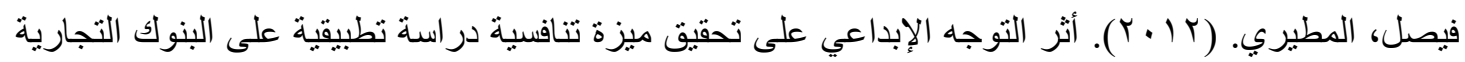
الكويتية الأردن - عمان. جامعة الثرق الأوسط ، الأردن. 32- نوير، طارق. (1 (ب). الوضع التنافسي للصناعات الكيماوية في مصر في ضوء التطور ات المحلية والعالمية

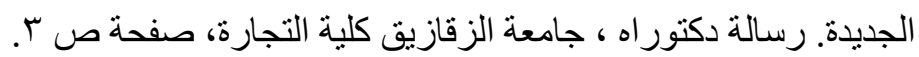
حجازي، ياسمين صبري محمود (2014). استخدام إنترنت الأشياء كأداة لتحقيق تنافسية السياحة الإبداعية بمناطق

الترات بمدينة الفيوم" موتمر تفاقات المتوسط في الفنون و العمارة، كلية فنون جميلة جامعة الإسكندرية، ص ا. .

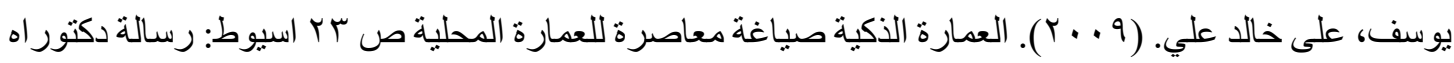

